\title{
Cross-presentation of the oncofoetal tumor antigen 5T4 from irradiated prostate cancer cells - a key role for Hsp70
}

\author{
Josephine C Salimu', Lisa K Spary', Saly Al-Taei², Aled Clayton, Malcolm Mason', John Staffurth, \\ Zsuzsanna Tabi ${ }^{1 *}$
}

From Society for Immunotherapy of Cancer 29th Annual Meeting

National Harbor, MD, USA. 6-9 November 2014

Immune responses contribute to the success of radiation therapy of solid tumors; however, the mechanism of triggering $\mathrm{CD}^{+} \mathrm{T}$ cell responses is poorly understood. Antigen cross-presentation from tumor cells by dendritic cells (DC) is a likely dominant mechanism to achieve $\mathrm{CD}^{+} \mathrm{T}$ cell stimulation. We established a cross-presentation model in prostate cancer in which DC present a naturally expressed oncofoetal tumor antigen (5T4) from irradiated DU145 tumor cells to 5T4-specific T cells. Ionising radiation (12 Gy) caused G2/M cell cycle arrest and cell death, increased cellular 5T4 levels, induced passive release of high-mobility protein group-B1 (HMGB1) and upregulated surface calreticulin and Hsp70 expression in DU145 cells. Co-culture of DC with irradiated tumor cells lead to efficient phagocytosis of tumor cells and upregulation of CD86 and HLA-DR on DC. CD8 ${ }^{+}$5T4-specific T cells, stimulated with these DC, proliferated and produced IFN $\gamma$. Inhibition of HMGB1 function decreased T cell stimulation but not DC activation, while TRIF/MyD88 inhibition only had a marginal effect on $\mathrm{T}$ cell stimulation. Unlike previous reports, we found no functional evidence that $\mathrm{DC}$ with Asp299Gly toll-like receptor-4 (TLR4) single nucleotide polymorphism had impaired ability to cross-present tumor antigen. However, we observed a highly significant and robust prevention of antigen cross-presentation when tumor cells were pre-treated with the novel Hsp70 inhibitor, VER155008. The inhibitor also prevented CD86 upregulation on DC co-cultured with irradiated tumor cells. Together, our study demonstrates that radiation induces immunologically relevant changes in tumor cells, which

'Cardiff University, Cardiff, UK

Full list of author information is available at the end of the article can trigger $\mathrm{CD}^{+} \mathrm{T}$ cell responses via a predominantly Hsp70-dependent antigen cross-presentation process.

Authors' details
${ }^{1}$ Cardiff University, Cardiff, UK. ${ }^{2}$ Velindre NHS Trust, Cardiff, UK.

Published: 6 November 2014

doi:10.1186/2051-1426-2-S3-P161

Cite this article as: Salimu et al:: Cross-presentation of the oncofoetal tumor antigen 5T4 from irradiated prostate cancer cells - a key role for Hsp70. Journal for ImmunoTherapy of Cancer 2014 2(Suppl 3):P161.

Submit your next manuscript to BioMed Central and take full advantage of:

- Convenient online submission

- Thorough peer review

- No space constraints or color figure charges

- Immediate publication on acceptance

- Inclusion in PubMed, CAS, Scopus and Google Scholar

- Research which is freely available for redistribution 